\title{
Interleukin 1 Induces HIV-1 Expression in Chronically Infected U1 Cells: Blockade by Interleukin 1 Receptor Antagonist and Tumor Necrosis Factor Binding Protein Type 1
}

\author{
Eric V. Granowitz, Bradford M. Saget, Monica Z. Wang, \\ Charles A. Dinarello, and Paul R. Skolnik \\ Department of Medicine, Division of Geographic Medicine and \\ Infectious Diseases, New England Medical Center Hospitals; Tupper \\ Research Institute; and Tufts University School of Medicine, Boston, \\ Massachusetts, U.S.A.
}

\begin{abstract}
Background: Cytokines and cytokine antagonists modulate human immunodeficiency virus (HIV) replication in vitro and may be involved in HIV disease pathogenesis. An understanding of these cytokine networks may suggest novel treatment strategies for HIV-seropositive persons.

Materials and Methods: U1 cells, a chronically infected promonocytic cell line, were stimulated with interleukin $1 \alpha$ (IL- $1 \alpha)$, IL- $1 \beta$ or tumor necrosis factor (TNF) for $24 \mathrm{hr}$. The effects of these cytokines, and of anti-IL-1 receptor type 1 and type 2 (IL-1RI and II) antibody, IL-1 receptor antagonist (IL-lRa), and recombinant human TNF binding protein type 1 (rhTBP-1, a form of TNF receptor p55), on HIV-1 replication, as measured by ELISA for HIV-1 p24 antigen, were determined. The effects of IL-1 and IL-1Ra on nuclear factor $-\kappa \mathrm{B}(\mathrm{NF}-\kappa \mathrm{B})$ DNA binding activity, as measured by electrophoretic mobility shift assays, were also determined.
\end{abstract}

Results: IL- $1 \alpha$ and IL- $1 \beta$ increased p 24 antigen production in a concentration-dependent manner. IL-1 Ra completely, and rhTBP-1 partially, suppressed IL-1-induced p24 antigen production. IL-1 increased NF- $\kappa$ B DNA binding activity and IL-1Ra blocked this effect. Since IL-1Ra blocks IL-1 from binding to both the IL-1RI and IL-1RII, monoclonal antibodies directed against each receptor were used to ascertain which IL-1R mediates IL1 -induced HIV-1 expression. Antibody to the IL-1RI reduced IL-1-induced p24 antigen production. Although anti-IL-1RII antibody blocked the binding of ${ }^{125} \mathrm{IL}-1-1 \alpha$ to Ul cells by $99 \%$, this antibody did not affect IL-1induced p 24 antigen production. IL- $1 \beta$ enhanced TNF $\alpha$ induced HIV expression when added before or simultaneously with TNF $\alpha$.

Conclusions: IL- 1 induces HIV-1 expression (via the IL-1RI) and NF- $\kappa \mathrm{B}$ activity in Ul cells. These effects are blocked by IL-1Ra and partially mediated by TNF. IL-1 enhances TNF $\alpha$-induced HIV replication in Ul cells.

\section{INTRODUCTION}

Interleukin $1 \alpha(\mathrm{IL}-1 \alpha)$ and IL- $1 \beta$ are two distinct gene products that share a spectrum of inflammatory and immunological properties (1). Both cytokines bind to the $80-\mathrm{kD}$ type I IL- 1 receptor

Address correspondence and reprint requests to: Paul $\mathrm{R}$. Skolnik, Division of Geographic Medicine and Infectious Diseases, New England Medical Center Hospitals, 750 Washington Street, NEMCH \#67, Boston, MA 02111, U.S.A.
(IL-1RI) found on T cells (2-4) and fibroblasts (2). The $68-\mathrm{kD}$ type II IL-1 receptor (IL-1RII) on monocytes (5), B cells (3), and neutrophils (6) also binds both forms of IL-1. The two IL-1Rs have $28 \%$ amino acid identity between their extracellular domains; however, the cytoplasmic portion of the IL-1RII is truncated compared with that of the IL-1RI (7). There is considerable evidence that IL- 1 exerts its biological effects via the IL-1RI. In HepG2 cells expressing both the 
IL-1RI and IL-1RII, anti-IL-1RI antibody completely abrogates IL- 1 -induced activation of T669 protein kinase (8). Anti-IL-1RI antibody also blocks IL-1-induced nuclear factor- $\kappa \mathrm{B}$ (NF- $\kappa \mathrm{B})$ synthesis in B cells possessing only $10 \mathrm{IL}-1 \mathrm{RI}$ per cell (9). It has been shown that anti-IL-1RII antibody does not inhibit, but in fact enhances IL1-induced cytokine synthesis in IL-1RII-bearing cells $(10,11)$.

Naturally occurring cytokine antagonists or soluble receptors can block the effects of certain cytokines. Interleukin 1 receptor antagonist (IL$\mathrm{l}$ Ra) blocks IL- 1 activity both in vivo and in vitro (reviewed in Ref. 12). Although it shares considerable sequence homology with IL- $1 \alpha$ and IL- $1 \beta$, and binds to the IL-1RI and IL-1RII $(13,14)$ on various cells, it has no known agonist activity. In contrast to monoclonal antibodies to interleukin-1 receptors, IL-1Ra has been used in several clinical trials; it has been well tolerated and has not had any demonstrable agonist activity in humans (1). Similarly, tumor necrosis factor (TNF) soluble receptors can block the effects of TNF. There are two soluble TNF receptors (sTNFRp55 and sTNFRp75; reviewed in Ref. 15). In these studies, we used recombinant human TNF binding protein type 1 (rhTBP- 1$)$, a form of sTNFRp55, to block TNF agonist activity.

Studies performed in chronically HIV-1-infected promonocytic (Ul) and T lymphocytic $(\mathrm{ACH}-2)$ cell lines have demonstrated that cytokines such as granulocyte-macrophage colonystimulating factor (16), TNF (17), IL-6 (18), and interferon- $\gamma(19)$ enhance human immunodeficiency virus type 1 (HIV-1) expression. TNF appears to mediate its effect on HIV-1 by increasing the amount of free NF- $\kappa$ B that in turn binds to and stimulates the HIV-1-long terminal repeat $(20-22)$. IL-1 has also been shown to activate HIV-1 LTR expression $(22,23)$ and HIV-1 replication (24), contrary to earlier reports (16).

In this study, we investigated the effect of IL- 1 on HIV- 1 expression and NF- $\kappa$ B DNA binding activity in $U 1$ cells and examined the function of each IL-1R using specific monoclonal antibodies. Additional experiments were performed to evaluate the ability of interleukin 1 receptor antagonist (IL-1Ra) and recombinant human TNF binding protein type 1 (rhTBP-1) to block IL-1-induced HIV-1 replication. We found that IL- 1 induces HIV-1 replication via the IL-1RI in $\mathrm{Ul}$ cells in association with increases in NF- $\kappa \mathrm{B}$ DNA binding activity. These effects are blocked completely by IL-1Ra and partially by rhTBP-1. These data provide further insight into factors that control HIV-1 replication in chronically infected monocytes.

\section{MATERIALS AND METHODS Reagents}

Human recombinant IL- $1 \alpha\left(2 \times 10^{8} \mathrm{U} / \mathrm{mg}\right)$ was the gift of Dr. Peter Lomedico (Hoffmann-LaRoche, Nutley, NJ, U.S.A.). Human recombinant IL- $1 \beta\left(10^{8} \mathrm{U} / \mathrm{mg}\right)$ was donated by Dr. Aldo Tagliabue (Sclavo Research Centre, Sienna, Italy). These cytokines contained $<100 \mathrm{pg} / \mathrm{mg}$ of endotoxin as determined by the Limulus amebocyte lysate test (Associates of Cape Cod, Woods Hole, MA, U.S.A.). Human recombinant IL-1 receptor antagonist (IL-1Ra) was provided by Dr. Daniel E. Tracey (Upjohn, Kalamazoo, MI, U.S.A.). Human recombinant $\mathrm{TNF} \alpha\left(10^{7} \mathrm{U} / \mathrm{mg}\right)$ was the gift of Dr. Michael A. Palladino, Jr. (Genentech Inc., So. San Francisco, CA, U.S.A.). Recombinant human TNF binding protein-1 (rhTBP-1) was produced in Chinese hamster ovary cells and was donated by Ares Advanced Technology, Inc. (Ares Serono), Randolph, MA, U.S.A. Murine anti-human IL-1RI (M1) and IL-1RII (M22) monoclonal antibodies were provided by Dr. John E. Sims (Immunex, Seattle, WA, U.S.A.). Phorbol myristate acetate (PMA) (Sigma Chemical Co., St. Louis, MO, U.S.A.) was diluted to 2.5 $\mathrm{mg} / \mathrm{ml}$ in dimethylsulfoxide (Sigma) and stored at $-20^{\circ} \mathrm{C}$. Radiolabeling of IL- $1 \alpha$ with ${ }^{125}$ I (New England Nuclear, Boston, MA, U.S.A.) was performed using chloramine $\mathrm{T}$ (Sigma).

RPMI 1640 (Sigma) containing $10 \mathrm{mM} \mathrm{L}$ glutamine, $24 \mathrm{mM} \mathrm{NaHCO}_{3}$ (Mallinckrodt, Paris, KY, U.S.A.), $10 \mathrm{mM}$ Hepes (Sigma), $100 \mathrm{U} / \mathrm{ml}$ penicillin, and $100 \mu \mathrm{g} / \mathrm{ml}$ streptomycin (Irvine Scientific, Santa Ana, CA, U.S.A.), pH 7.4, was ultrafiltered using polysulfone hollow fiber filters (F40; Fresenius AG, Bad Homburg, Germany) to remove substances capable of inducing cytokine production (25). For all experiments except the binding assays, RPMI was supplemented with heat-inactivated $\left(45 \mathrm{~min}, 56^{\circ} \mathrm{C}\right)$ fetal calf serum (FCS; $10 \%$ final concentration; HyClone Laboratories, Logan, UT, U.S.A.). The binding assay buffer consisted of ultrafiltered RPMI with bovine serum albumin ( $1 \%$ final concentration, Fraction V, Sigma), $20 \mathrm{mM}$ Hepes, and $0.05 \%$ sodium azide (Sigma), pH 7.2. 


\section{Phytohemagglutinin-Stimulated Peripheral Blood Mononuclear Cell Supernatants}

Peripheral blood mononuclear cells (PBMC) were obtained using ficoll-hypaque centrifugation as previously described (14). Cells were then cultured at $2.5 \times 10^{6}$ cells $/ \mathrm{ml}$ in RPMI supplemented with $10 \%$ FCS and $0.5 \mathrm{mg} / \mathrm{ml}$ phytohemagglutinin (PHA)-P (Sigma) at $37^{\circ} \mathrm{C}$ in a humidified atmosphere containing $5 \% \mathrm{CO}_{2}$. After $24 \mathrm{hr}$, the cell suspension was centrifuged at 350 $\times g$ for $10 \mathrm{~min}$. The supernatant was removed and frozen at $-70^{\circ} \mathrm{C}$.

\section{U1 Cell Line}

The Ul cell line is a subclone of HIV-1-infected U937 promonocytic cells (16). U1 cells contain two copies of HIV-l proviral DNA and constitutively express low levels of virus. These cells were obtained from the AIDS Research and Reference Program, NIAID, National Institutes of Health, and were cultured in RPMI containing $10 \%$ FCS. Preliminary experiments were performed to determine the optimal cell density and the kinetics of HIV-1 p24 antigen production after cytokine stimulation using our in vitro culture conditions (data not shown). Based on these results, in each experiment Ul cells were washed twice in RPMI before being resuspended in RPMI/FCS at a concentration of $2 \times 10^{6} \mathrm{cells} / \mathrm{ml}$. Cells $(500 \mu \mathrm{l})$ were then aliquoted into $12 \times 75$ $\mathrm{mm}$ round bottom polypropylene tubes (Falcon, Becton Dickinson, Lincoln Park, NJ, U.S.A.) and $250 \mu \mathrm{l}$ of either RPMI/FCS or an inhibitor in RPMI/FCS was added. Immediately thereafter, cultures were supplemented with $250 \mu \mathrm{l}$ of either RPMI/FCS or IL-1 in RPMI/FCS. For every experiment, each condition was tested in quadruplicate. In the experiments using anti-IL-1R monoclonal antibody, cells were preincubated with antibody for $90 \mathrm{~min}$ at $37^{\circ} \mathrm{C}$ prior to the addition of IL-1. Cells were then incubated for 24 hr at $37^{\circ} \mathrm{C}, 5 \% \mathrm{CO}_{2}$.

After incubation, cell viability was determined by trypan blue exclusion. Cultures were then mixed with Triton X-100 $(0.5 \%$ final concentration; Du Pont/NEN Research Products, Boston, MA, U.S.A.) and frozen at $-70^{\circ} \mathrm{C}$. Where indicated, cells were separated from the supernatant prior to the addition of Triton $\mathrm{X}$. In these experiments, cell suspensions were centrifuged at $300 \times g$ for $5 \mathrm{~min}$; supernatants were removed, combined with Triton $\mathrm{X}$, and frozen at $-70^{\circ} \mathrm{C}$. Cell pellets were washed once with RPMI, resuspended in $1000 \mu \mathrm{l}$ RPMI with $10 \%$ FCS, mixed with Triton X-100, and then frozen at $-70^{\circ} \mathrm{C}$. Unseparated $\mathrm{U} l$ cell suspensions, cells alone, and supernatants were assayed for p24 antigen by ELISA (Du Pont/NEN). IL- $1 \alpha$, IL- $1 \beta$, IL-1Ra, and rhTBP-1 do not interfere with this ELISA (data not shown). The limit of detection of the ELISA was $12.5 \mathrm{pg} / \mathrm{ml} \mathrm{p} 24$ antigen.

\section{Electrophoretic Mobility Shift Assays}

NF- $\kappa \mathrm{B}$ probe was isolated from a 93-bp HaeIII fragment from pHIVlacZ (NIAID AIDS Research and Reference Reagent Program) that was subsequently treated with alkaline phosphatase, then 5 '-end labeled. Cellular and nuclear extracts were isolated according to the method by Dignam et al. (26) and Andrews and Faller (27), respectively. Briefly, labeled NF- $\kappa$ B probe was incubated with $20 \mu \mathrm{g}$ cellular extract or $10 \mu \mathrm{g}$ nuclear extract and $1.5 \mu \mathrm{g}$ poly (dI:dC) for 30 min at room temperature. The binding reaction contained $10 \mathrm{mM}$ Tris- $\mathrm{HCl}(\mathrm{pH} 7.5), 50 \mathrm{mM}$ $\mathrm{NaCl}, 1 \mathrm{mM}$ dithiothreitol, $1 \mathrm{mM}$ EDTA, and 5\% glycerol in a final volume of $25 \mu \mathrm{l}(28)$. Bound and unbound fractions were separated on a $4 \%$ polyacrylamide gel with $50 \mathrm{mM}$ Tris- $\mathrm{HCl}(\mathrm{pH}$ $8.5), 380 \mathrm{mM}$ glycine, and $2 \mathrm{mM}$ EDTA (29) as the running buffer. Gels were dried and exposed to Kodak SB-5 X-ray film at $-70^{\circ} \mathrm{C}$.

\section{Receptor Binding Assay}

Using the methods of Spriggs et al. (5), Ul cells were suspended at $10^{6}$ cells $/ \mathrm{ml}$ in RPMI with $10 \%$ FCS and $5 \mathrm{ng} / \mathrm{ml}$ phorbol myristate acetate (PMA). After incubating for $24 \mathrm{hr}$ at $37^{\circ} \mathrm{C}$, dexamethasone $\left(10^{-7} \mathrm{M}\right.$ final concentration) was added and the cells were incubated for an additional $14 \mathrm{hr}$. Subsequently, the cells were centrifuged at $300 \times g$ for $10 \mathrm{~min}$. The cell pellet was then resuspended for $15 \mathrm{sec}$ at $4^{\circ} \mathrm{C}$ in $500 \mu \mathrm{l}$ of $150 \mathrm{mM}$ sodium chloride, $100 \mathrm{mM}$ glycine $\mathrm{HCl}$, $\mathrm{pH} 3.2$, before being diluted to $50 \mathrm{ml}$ in $4^{\circ} \mathrm{C}$ PBS.

Ul cells were washed twice in cold RPMI before being resuspended at $10^{8}$ cells $/ \mathrm{ml}$ in $4^{\circ} \mathrm{C}$ binding buffer. Duplicate aliquots of cells were gently rocked for $2 \mathrm{hr}$ at $4^{\circ} \mathrm{C}$ with different concentrations of anti-IL-1RII monoclonal antibody or IL-1Ra. Radiolabeled IL- $1 \alpha$ was added. The total volume of the cell suspension was $150 \mu \mathrm{l}$. After the samples were rocked for another $2 \mathrm{hr}$ at $4^{\circ} \mathrm{C}$, cell bound radioactivity was separated from free radioactivity by centrifugation through oil (Sil- 
icones, General Electric, Waterford, NY, U.S.A.) at $14,000 \times g$ for $90 \mathrm{sec}$. Tips of the tubes containing the cell pellet were cut and counted. Radioactivity was measured using a $\gamma$-scintillation counter.

\section{Statistics}

Data are expressed as mean \pm SD. Percentage inhibition was calculated using the formula:

[p24 antigen] in presence of inhibitor constitutive (p24 antigen)] $\times 100$

IL-1 -induced (p24 antigen) - constitutive (p24 antigen)

Staiictical analysis was performed using the two-tailed Student's $t$ test for unpaired samples and analysis of variance using Fischer's least significant difference.

\section{RESULTS}

\section{IL-1 Induces HIV-1 Expression in U1 Cells}

In the present study, we investigated whether IL- 1 could increase p24 antigen production in the chronically HIV-l-infected promonocytic Ul cell line. Ul cells were cultured with increasing concentrations of IL-1. In 11 experiments, IL-1 induced a 2- to 7-fold increase in p24 antigen synthesis. Similar results were obtained using either IL- $1 \alpha$ or IL- $1 \beta$. As illustrated in Fig. 1 , IL- 1 induced a concentration-dependent increase in p24 antigen production $(p<0.001)$. The effective dose $_{50}$ for IL-1 was $1 \mathrm{ng} / \mathrm{ml}(p<0.05)$. Maximal induction occurred at $10 \mathrm{ng} / \mathrm{ml} \mathrm{IL-1}$ $(p \leq 0.001)$. IL-1 did not affect cell viability or proliferation at $50 \mathrm{ng} / \mathrm{ml}$ (data not shown).

\section{IL-1 Increases Both Cell-Associated and Released HIV-1 Protein}

To ascertain if IL-1 induced viral protein release, we measured the cell-associated and supernatant p24 antigen concentrations in unstimulated and IL-1-stimulated cultures (Fig. 2). In unstimulated U1 cells, $58 \%$ of the p24 antigen was cell-associated $(p=0.01$ when compared with supernatant p24 antigen). Cell-associated p24 antigen constituted 59\% $(p<0.001)$ and $61 \%(p<$ $0.001)$ of IL- $1 \alpha$ and IL- $1 \beta$-induced p 24 antigen synthesis, respectively. Therefore, IL-1 increases both cell-associated and released HIV-1 p24.

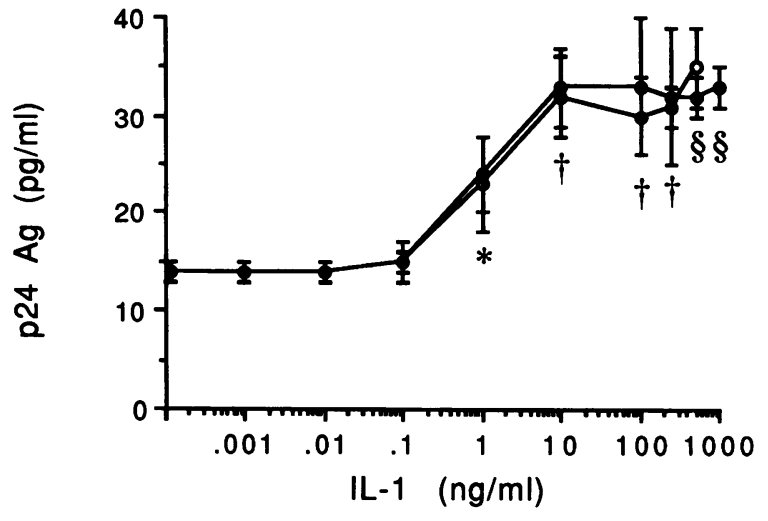

FIG. 1. IL-1-induced HIV-1 p24 antigen production is concentration dependent

Ul cells were cultured with increasing concentrations of IL- $1 \alpha(O)$ or IL- $1 \beta(0)$. After $24 \mathrm{hr}$ cells were lysed with Triton X-100. An ELISA was performed to determine the total concentration of $\mathrm{p} 24$ antigen. Each data point depicts the mean \pm SD of four samples. ${ }^{*} p<0.05 ;{ }^{\dagger} p \leq 0.01$; and ${ }^{{ }} p \leq 0.001$ when comparing Ul cells stimulated with IL-1 with unstimulated cells. $p<0.001$ using analysis of variance.

\section{IL-1Ra Blocks IL-1-Induced HIV-1 Expression}

IL-1Ra was added to Ul cells immediately prior to the addition of $50 \mathrm{ng} / \mathrm{ml} \mathrm{IL-1.} \mathrm{Constitutive}$ p24 antigen synthesis $(17 \pm 1 \mathrm{pg} / \mathrm{ml})$ was unaf-

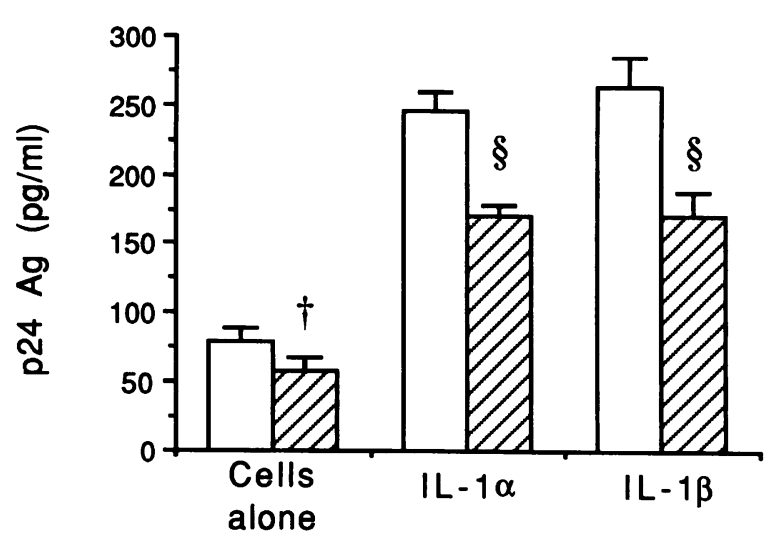

FIG. 2. IL-1 increases both cell-associated and released p24 antigen

Ul cells were cultured in the absence or presence of $50 \mathrm{ng} / \mathrm{ml} \mathrm{IL}-1 \alpha$ or IL-1 $\beta$. After $24 \mathrm{hr}$ the concentrations of cell-associated (open bars) and supernatant (hatched bars) p24 antigen were determined by ELISA. Each data point depicts the mean $\pm \mathrm{SD}$ of four samples. ${ }^{\dagger} p=0.01$ and ${ }^{\S} p<$ 0.001 when comparing cell-associated p24 antigen with supernatant p24 antigen. 


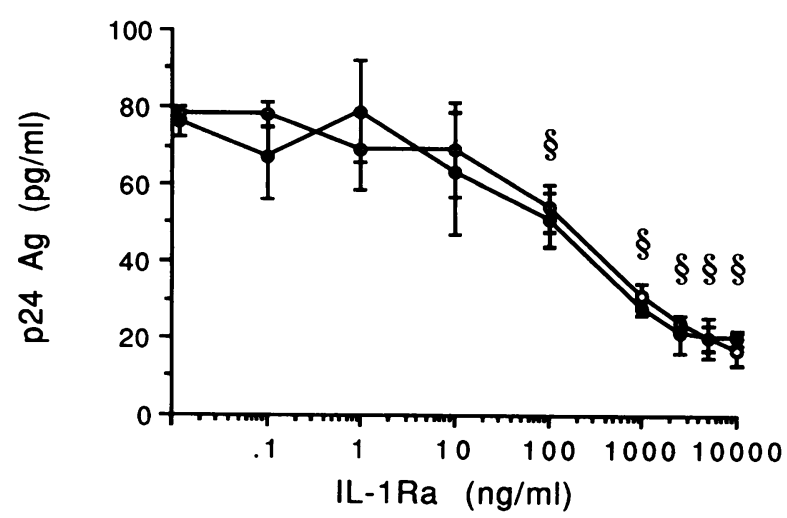

FIG. 3. IL-1Ra blocks IL-1-induced p24 antigen production

Ul cells were cultured with different concentrations of IL-1 Ra and then stimulated with $50 \mathrm{ng} / \mathrm{ml}$ IL- $1 \alpha$ (○) or IL-1 $\beta(O)$. p24 antigen is depicted as the mean \pm SD of four samples. ${ }^{\S} p \leq 0.001$ when comparing Ul cells pretreated with IL-1 Ra with cells not treated with IL-1Ra. $p<0.001$ using analysis of variance.

fected by incubation with $10 \mu \mathrm{g} / \mathrm{ml} \mathrm{IL-1Ra} \mathrm{(data}$ not shown). As depicted in Fig. 3, a 2-fold molar excess of IL- 1 Ra inhibited IL- $1 \beta$-induced p 24 antigen production by $50 \%(p \leq 0.001)$. At a 50 fold molar excess, IL-1Ra completely suppressed IL- $1 \beta$-induced p24 antigen $(p<0.001)$.

\section{IL-1Ra Does Not Block PHA-Supernatant-, TNF $\alpha-$, or PMA-Induced HIV-1 Expression}

PHA-supernatant $(25 \% \mathrm{v} / \mathrm{v})$ induced a 6 -fold rise in p24 antigen synthesis. Constitutive p24 antigen synthesis was $50 \pm 10 \mathrm{pg} / \mathrm{ml}$ in this experiment. Ul cells stimulated with $10 \mathrm{ng} / \mathrm{ml}$ TNF $\alpha$ or $10^{-7}$ M PMA produced 5,100 \pm 300 $\mathrm{pg} / \mathrm{ml}$ and $22,000 \pm 3,800 \mathrm{pg} / \mathrm{ml} \mathrm{p} 24$ antigen, respectively. IL- $1 \mathrm{Ra}$, at a concentration of 10 $\mu \mathrm{g} / \mathrm{ml}$, did not inhibit PHA-supernatant-, TNF $\alpha$-, or PMA-induced p24 antigen production (data not shown).

\section{IL-I Increases NF- $\kappa$ B DNA Binding Activity and IL-IRa Blocks This Effect}

In order to determine whether the observed IL$1 \beta$-induced HIV replication was NF- $\kappa \mathrm{B}$ dependent, the electrophoretic mobility shift assay (EMSA) was employed to measure the level of transcriptionally active NF- $\kappa \mathrm{B}$ in cells treated with IL- $1 \beta$ and IL- 1 Ra. The results presented in Fig. 4 show that IL- $1 \beta(10 \mathrm{ng} / \mathrm{ml})$ induced NF- $\kappa B$

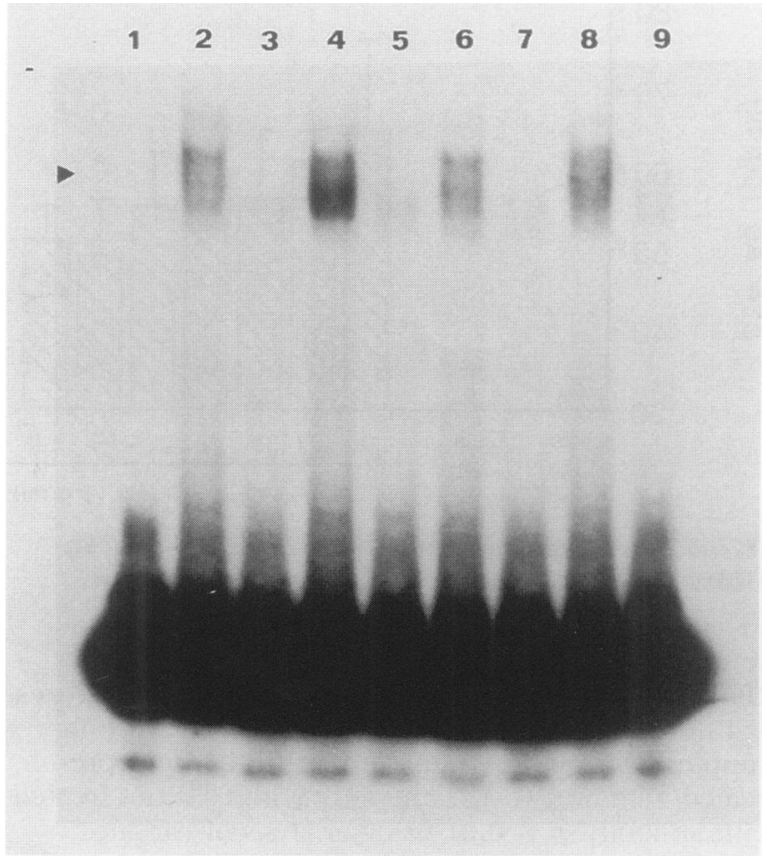

FIG. 4. IL-1 increases NF- $\mathrm{KB}$ DNA binding activity in U1 cells and IL-1Ra blocks IL-1induced NF- $\kappa$ B binding activity

Ul cells were stimulated with IL- $1 \beta(10 \mathrm{ng} / \mathrm{ml})$ and cultured for $3 \mathrm{hr}$ in the presence of IL-1 Ra (1 $\mu \mathrm{g} / \mathrm{ml})$. Gel mobility shift assays for NF- $\kappa$ B DNA binding activity were performed using $20 \mu \mathrm{g}$ of nuclear extracts, a NF- $\kappa \mathrm{B}$ probe and a NF- $\kappa \mathrm{B}$ consensus sequence as a competitor (20 ng). The arrowhead indicates the region of NF- $\kappa \mathrm{B}$ binding. (Lane 1) Unbound probe; (Lane 2) unstimulated Ul cells; (Lane 3 ) unstimulated Ul cells with NF- $\kappa$ B competitor sequence; (Lane 4) Ul cells with IL-1; (Lane 5) Ul cells with IL-1 and competitor; (Lane 6) Ul cells with IL-1Ra; (Lane 7) Ul cells with IL- 1 Ra and competitor; (Lane 8) Ul cells with IL-1 and IL-1Ra; (Lane 9) U1 cells with IL-1, IL-1Ra and competitor.

levels approximately two-fold above the unstimulated control (Lanes 2 and 4 ). IL-1 $\beta$-induced NF- $\kappa$ B activity was decreased in the presence of $1 \mu \mathrm{g} / \mathrm{ml}$ IL-1Ra to levels seen with unstimulated Ul cells (Lanes 2 and 8). EMSA results were similar when either cellular or nuclear extracts were used (data not shown). Similar results were obtained in three separate experiments.

\section{IL-1 Induces HIV-1 Expression via the IL-1RI}

IL-1Ra blocks the binding of IL-1 to both the IL-1RI (30) and the IL-1RII (13). To determine if 


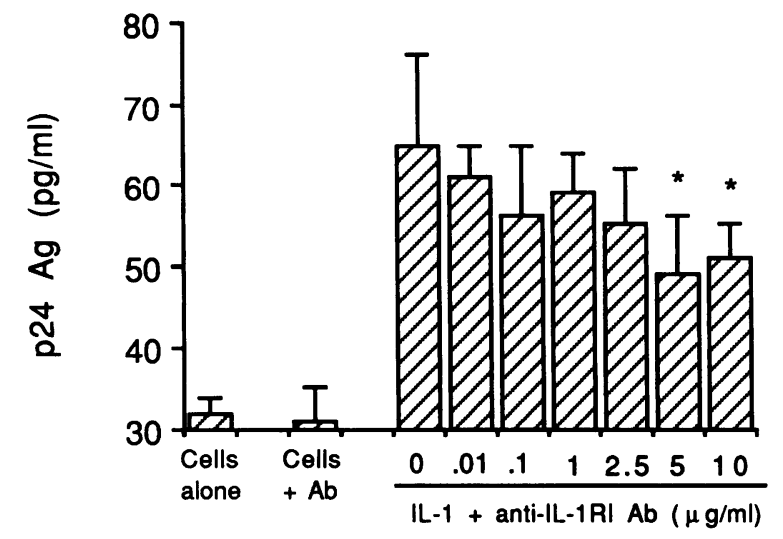

FIG. 5. Anti-IL-1RI monoclonal antibody inhibits IL-1-induced p24 antigen production Ul cells were incubated with different concentrations of anti-IL-1RI antibody. After $90 \mathrm{~min}$, either RPMI or IL- $1 \beta(50 \mathrm{ng} / \mathrm{ml})$ was added to the cultures. p24 antigen is depicted as the mean \pm SD of four samples. ${ }^{\star} p=0.05$ when comparing Ul cells pretreated with anti-IL-1RI antibody with cells not treated with antibody. $p=0.01$ using analysis of variance.

the IL-1RI mediated IL-1-induced increases of p24 antigen levels in Ul cells, these cells were preincubated with murine anti-human IL-IRI monoclonal antibody prior to stimulation with IL- $1 \beta$ (Fig. 5). Antibody alone did not stimulate an increase in HIV-1 expression. However, antiIL-1RI antibody inhibited IL-1-induced p24 antigen production in a concentration-dependent manner $(p=0.001)$. At a concentration of 5 $\mu \mathrm{g} / \mathrm{ml}$, this antibody reduced p24 antigen synthesis by $42 \%(p=0.05)$.

\section{Antibody to the IL-1RII Blocks the Binding of IL-1 to U1 Cells, but Does Not Inhibit IL-1-Induced HIV-1 Expression}

Human monocytes can be induced to express large amounts of IL-1RII (5). We therefore examined whether anti-human IL-1RII monoclonal antibody could inhibit IL-1-induced p24 antigen production. As shown in Fig. $6,2.5 \mu \mathrm{g} / \mathrm{ml}$ anti-IL-1RII antibody blocked the binding of ${ }^{125} \mathrm{IL}-1 \alpha$ to U1 cells by $98 \%$. However, as depicted in the inset, $10 \mu \mathrm{g} / \mathrm{ml}$ of this antibody did not inhibit IL- $1 \alpha$-induced p 24 antigen synthesis. Similar results were obtained using IL- $1 \beta$ as the stimulant (data not shown).

\section{IL-1 Enhances TNF $\alpha$-Induced HIV-1 Expression}

Folks et al. (17) demonstrated that TNF $\alpha$ increases HIV-1 expression. Since IL-1 and TNF $\alpha$

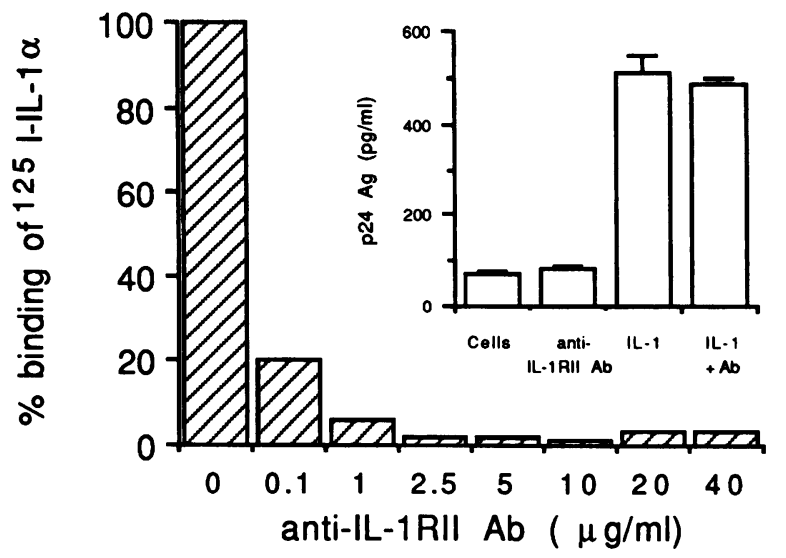

FIG. 6. Anti-IL-1RII monoclonal antibody blocks the binding of radiolabeled IL-1 to U1 cells, but does not inhibit IL-1-induced p24 antigen production

Ul cells $\left(10^{7}\right)$ were preincubated for $2 \mathrm{hr}$ at $4^{\circ} \mathrm{C}$ with different concentrations of anti-IL-1RII antibody prior to the addition of $\sim 100 \mathrm{pM}{ }^{125} \mathrm{IL}-1 \alpha$. After another $2 \mathrm{hr}$ at $4^{\circ} \mathrm{C}$, specific binding was determined. Nonspecific binding (which was measured in the presence of $10 \mu \mathrm{M}$ of IL-1Ra) was $37 \%$ of total binding. The inset shows Ul cells preincubated with RPMI or $10 \mu \mathrm{g} / \mathrm{ml}$ anti-IL-1RII prior to stimulation with $50 \mathrm{ng} / \mathrm{ml} \mathrm{IL-1} \alpha$. p24 antigen is depicted as the mean \pm SD of four samples.

often act synergistically ( 31 ), we investigated the effect of a combination of IL- $1 \beta$ and TNF $\alpha$ on p24 antigen synthesis. As depicted in Fig. 7A, U1 cells were treated with IL- $1 \beta(5 \mathrm{ng} / \mathrm{ml})$ immediately prior to stimulation with increasing concentrations of TNF $\alpha$. Cells stimulated with IL-1 $\beta$ alone synthesized $42 \pm 5 \mathrm{pg} / \mathrm{ml} \mathrm{p} 24$ antigen. At concentrations of exogenous TNF $\alpha$ equal to or greater than $10 \mathrm{ng} / \mathrm{ml}$, IL- $1 \beta$ significantly enhanced TNF $\alpha$-induced p24 antigen synthesis, giving approximately a $40 \%$ increase in p24 antigen expression at $100 \mathrm{ng} / \mathrm{ml} \mathrm{TNF} \alpha$. Pretreatment for 24 hr with IL- $1 \beta$ also enhanced TNF $\alpha$ induced HIV-1 expression (Fig. 7B). Cells cultured with IL- $1 \beta(5 \mathrm{ng} / \mathrm{ml})$ and then stimulated for $24 \mathrm{hr}$ with TNF $\alpha(10 \mathrm{ng} / \mathrm{ml})$ contained 2.4-fold more p24 antigen than controls treated with TNF $\alpha$ alone $(p<0.01)$. Therefore, IL- $1 \beta$ enhances TNF $\alpha$-induced HIV-1 expression when added before or simultaneously with TNF $\alpha$.

\section{IL-1-Induced HIV-1 Expression Is Mediated in Part by TNF}

Monocytes stimulated with IL-1 synthesize TNF (32). To determine the contribution of endog- 

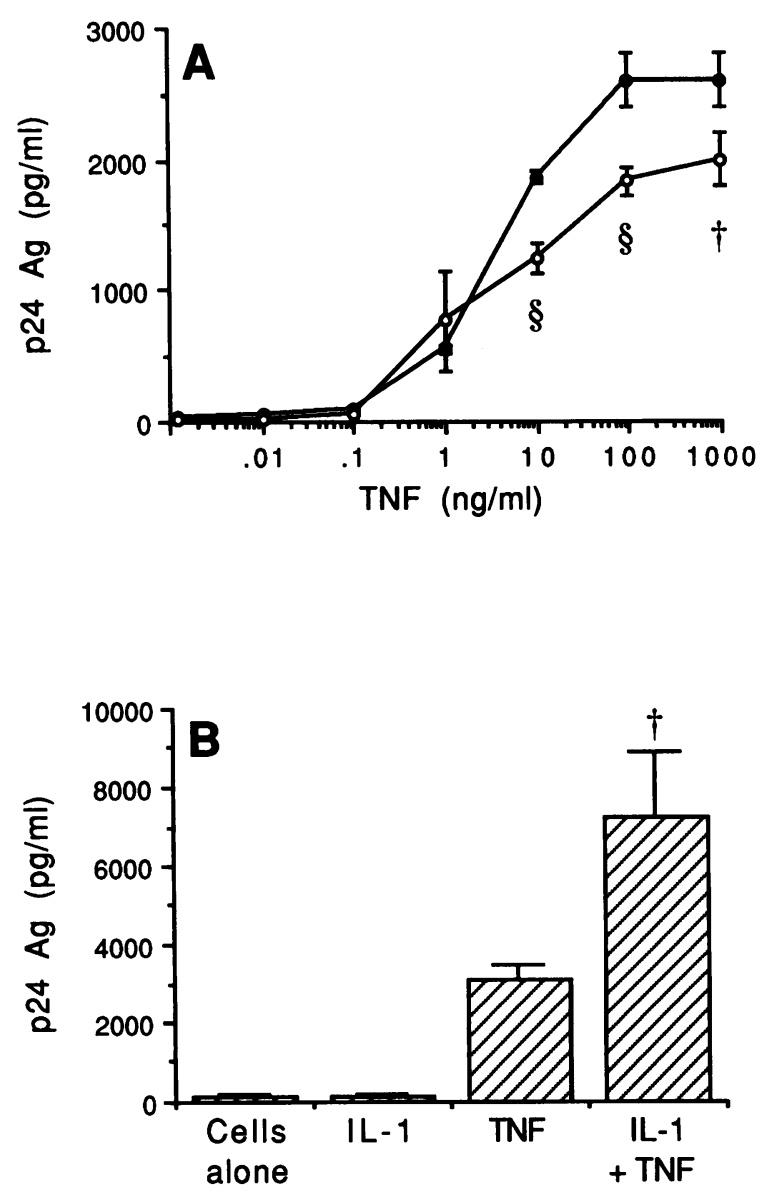

FIG. 7. IL-1 enhances TNF $\alpha$-induced p24 antigen production

(A) Ul cells were treated with RPMI $(O)$ or 5 $\mathrm{ng} / \mathrm{ml} \mathrm{IL-1} \beta(0)$ immediately prior to the addition of different concentrations of TNF $\alpha$. After $24 \mathrm{hr}$, p24 antigen concentrations were determined by ELISA. (B) Ul cells were cultured in the absence or presence of $5 \mathrm{ng} / \mathrm{ml} \mathrm{IL-1} \beta$ for $24 \mathrm{hr}$ before the addition of $10 \mathrm{ng} / \mathrm{ml} \mathrm{TNF} \alpha$. All cultures were assayed for p24 antigen $24 \mathrm{hr}$ following the addition of TNF $\alpha .{ }^{+} p \leq 0.01$ and ${ }^{\S} p \leq 0.001$ when comparing cells stimulated with both IL- $1 \beta$ and TNF $\alpha$ with cells stimulated with TNF $\alpha$ alone.

enously synthesized TNF to IL-1-induced p24 antigen production, $\mathrm{Ul}$ cells were incubated with $50 \mathrm{ng} / \mathrm{ml} \mathrm{IL-1}$ in the presence of rhTBP-1 (Fig. 8). rhTBP-1 inhibited IL- $1 \alpha$ - and IL- $1 \beta$ induced p24 antigen production by $27 \%(p<$ $0.001)$ and $24 \%(p=0.001)$, respectively.

\section{DISCUSSION}

IL- 1 is an inflammatory mediator capable of affecting nearly all mammalian cells. After binding to cells possessing both IL-1Rs, IL-1 activates nu-

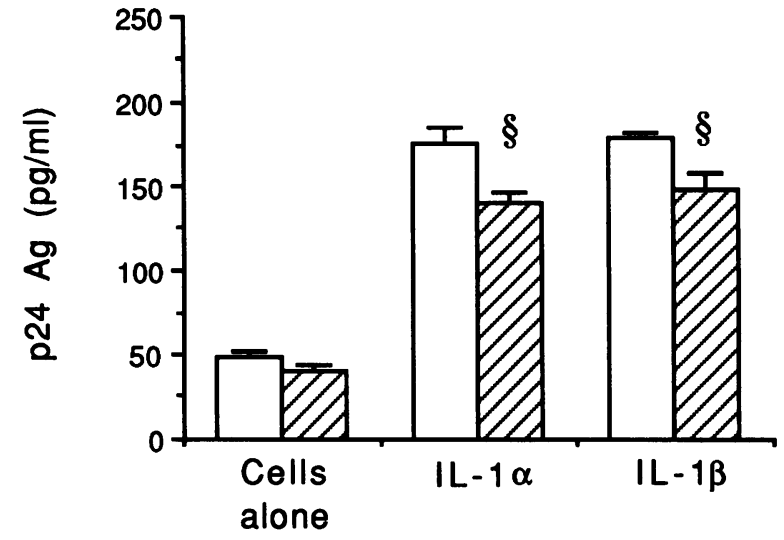

FIG. 8. rhTBP-1 inhibits IL-1-induced p24 antigen production

U1 cells were incubated in the absence (open bars) or presence (hatched bars) of rhTBP-1 (2.5 $\mu \mathrm{g} / \mathrm{ml}$ ) prior to stimulation with $50 \mathrm{ng} / \mathrm{ml}$ IL- 1 . p24 antigen is depicted as the mean \pm SD of four samples. ${ }^{\S} p \leq 0.001$ when comparing Ul cells treated with rhTBP-1 with cells not treated with rhTBP-1.

clear factors (33), stimulates transcription of proto-oncogenes (34), and induces cytokine synthesis (35). As reported here, IL-1 can also increase viral expression in the chronically HIV-1infected promonocytic Ul cell line.

While there is well-established evidence that IL- 1 exerts its effects via the IL-1RI, recent studies suggest that the IL-1RII does not mediate signal transduction $(10,11)$. Since Ul cells possess both the IL-IRI and the IL-1RII, we used these cells to investigate the different roles of the two IL-1Rs. Our data demonstrate that even though monoclonal antibody directed against the IL-1RII blocked IL-1 from binding to Ul cells, this antibody did not affect IL-1-induced p24 antigen production. In contrast, monoclonal antibody to the IL-1RI inhibited IL-1-induced p24 antigen synthesis. The lack of complete inhibition by anti-IL-1RI may be due in part to induction of HIV-1 by IL-1-induced TNF. Taken together, these findings demonstrate that the ILIRII does not participate in signal transduction either alone or in cooperation with the IL-1RI in this experimental system. This is in agreement with recently published data by Poli et al. (24).

By binding IL- 1 and therefore preventing its association with the IL-1RI, the IL-1RII might function as a downregulator of the immune response in conditions characterized by overproduction of IL-1. For example, during sepsis, neutrophils express an increased number of IL-1RII 
(36). Thus, the IL-IRII might act as a scavenger of excess IL-1. In contrast to other studies (24), we were unable to demonstrate this phenomenon in our system despite proving that anti-ILIRII blocked IL-1 binding to the receptor. One possible explanation for these differences is that the ratio of IL- 1 to IL- 1 receptors, which differed in these two studies, is an important factor. Whether there is already an increase in IL-1RII expression during asymptomatic HIV-1 infection is unknown. However, we do have evidence that plasma IL-1 Ra levels are elevated in both asymptomatic and symptomatic HIV-1-seropositive patients as compared with healthy HIV-1-seronegative controls (manuscript in preparation).

We found that IL-1 induces NF- $\kappa$ B DNA binding activity in Ul cells. IL-1Ra blocks this effect, presumably because it prevents IL-1 from binding to the type I receptor (9). Several cytokines, including TNF, are known to increase HIV replication or HIV-LTR activity in association with NF- $\kappa$ B induction $(20,22)$. Increased HIV expression and NF- $\kappa \mathrm{B}$ activity occur during monocyte differentiation (37) and NF- $\kappa \mathrm{B}$ activity is induced by HIV infection of monocytes (38). Our finding that IL- 1 induces NF- $\kappa$ B activity in association with increased HIV replication is in agreement with these observations and with those of others who examined the effects of IL-1 on HIVLTR activity using a different assay system (22). They stand in contrast to those of Poli et al. who used an experimental system with Ul cells that was similar to ours (24). We speculate that this difference may relate to the concentrations of IL- 1 that were used $(10 \mathrm{ng} / \mathrm{ml}$ in our experiments and $1 \mathrm{ng} / \mathrm{ml}$ in those of Poli et al.), or other methodologic details that included cell number, time of culture, method of cell lysis and binding buffers.

Circulating TNF $\alpha$ levels are increased in AIDS patients $(39,40)$. As demonstrated here, IL- 1 enhances TNF $\alpha$-induced HIV-1 expression. In addition, IL- 1 induces TNF $\alpha$ (32) and this IL-1-induced TNF $\alpha$ contributes $27 \%$ of the total amount of IL-1-induced p24 antigen synthesis, as evidenced by blocking with rhTBP-1. Previous studies have also demonstrated a role for endogenous TNF $\alpha$ in HIV-l expression. Tadmori et al. (41) reported that anti-TNF $\alpha$ antibody suppressed both the constitutive expression of the HIV-1-long terminal repeat in Epstein-Barr virus-transformed B cells and expression induced by PMA in U937 cells. Anti-TNF $\alpha$ antibody has also been shown to suppress PMA-induced reverse transcriptase activity in Ul cells (42). Using a chronically HIV-1- infected CD4+ promyelocytic clone, Butera et al. (43) found that the increase in reverse transcriptase activity induced by TNF $\alpha$ pulse treatment could be prevented by the subsequent addition of anti-TNF $\alpha$ monoclonal antibodies. Thalidomide, a selective inhibitor of TNF $\alpha$ synthesis, also inhibits granulocyte-macrophage colony-stimulating factor and IL-6-induced reverse transcriptase activity in Ul cells (44).

While the magnitude of IL-1-induced HIV replication in vitro is less than that observed with TNF (approximately 10-fold less, data not shown), there may nonetheless be important in vivo effects of IL-1 on HIV disease progression. This may occur because of differential production of IL- 1 and TNF in vivo or differential expression of IL-1 and TNF receptors or their naturally occurring antagonists under different conditions at different sites. Moreover, we have demonstrated potentially important enhancing effects of the concerted action of IL- 1 and TNF on HIV-1 replication and the induction of TNF by IL-1 in this system. It may therefore be important to block the action of both these cytokines in future therapeutic interventions of cytokine networks in HIV-1 seropositive persons. In this regard, we have used specific cytokine antagonists that are well tolerated in human volunteers (reviewed in Refs. 1 and 45), to block the effects of IL-1 in these experiments. IL-1Ra almost completely blocked the effects of IL-1 on HIV-1 replication and NF- $\kappa \mathrm{B}$ DNA binding activity. rhTBP-1 partially blocked the effects of IL-1 on HIV replication.

Our findings demonstrate that IL-1 induces HIV- 1 expression in U1 cells via the IL-1RI and that this effect is mediated in part by TNF. IL-1 also induces NF- $\kappa$ B DNA binding activity. IL- 1 Ra blocks IL-1-induced effects on both HIV-1 replication and NF- $\kappa \mathrm{B}$ activity. The intricate autocrine, paracrine, and juxtacrine effects of cytokines in HIV-1-seropositive persons at various stages of disease are not fully known. It is possible that cytokine antagonists may be of benefit in the treatment of these patients to decrease HIV-1 replication at times when cytokine production is increased.

\section{ACKNOWLEDGMENTS}

We thank John Coffin, F. Cozzolino, Leland Shapiro, John E. Sims, and M. Torcia for valuable assistance. Dr. Jeffrey A. Gelfand and Dr. Sheldon $M$. Wolff (deceased) provided encouragement, guidance, and support for this project. This 
research was supported by NIH grants T32 AI07389 (EVG and BMS), AI-15614 (CAD), and K08 AI-01046 and R01 AI33290 (PRS).

\section{REFERENCES}

1. Dinarello CA, Wolff SM. (1993) The role of interleukin-1 in disease. N. Engl. J. Med. 328: 106-113.

2. Dower SK, Call SM, Gillis S, Urdal DL. (1986) Similarity between the interleukin 1 receptors on a murine T-lymphoma cell line and on a murine fibroblast cell line. Proc. Natl. Acad. Sci. U.S.A. 83: 1060-1064.

3. Horuk R, Huang JJ, Covington M, Newton RC. (1987) A biochemical and kinetic analysis of the interleukin-1 receptor. Evidence for differences in molecular properties of IL-1 receptors. J. Biol. Chem. 262: 16275-16278.

4. Kilian PL, Kaffka KL, Stern AS, et al. (1986) Interleukin 1 alpha and interleukin 1 beta bind to the same receptor on T cells. J. Immunol. 136: 4509-4514.

5. Spriggs MK, Lioubin PJ, Slack J, et al. (1990) Induction of an interleukin-1 receptor (IL1R) on monocytic cells. J. Biol. Chem. 265: 22499-22505.

6. Rhyne JA, Mizel SB, Taylor RG, Chedid M, McCall CE. (1988) Characterization of the human interleukin 1 receptor on human polymorphonuclear leukocytes. Clin. Immunol. Immunopathol. 48: 354-361.

7. McMahan CJ, Slack JL, Mosley B, et al. (1991) A novel IL-1 receptor, cloned from $B$ cells by mammalian expresion, is expressed in many cell types. E.M.B.O. J. 10: 2821-2832.

8. Bird TA, Sleath PR, deRoos PC, Dower SK, Virca GD. (1991) Interleukin-1 represents a new modality for the activation of extracellular signal-regulated kinase/microtubuleassociated protein-2 kinase. Proc. Natl. Acad. Sci. U.S.A. 266: 22661-22670.

9. Stylianou E, O'Neill LAJ, Rawlinson L, Edbrooke MR, Woo P, Saklatvala J. (1992) Interleukin 1 induces NF- $\kappa$ B through its type I but not its type II receptor in lymphocytes. $J$. Biol. Chem. 267: 15836-15841.

10. Colotta F, Re F, Muzio M, et al. (1993) Interleukin-1 type II receptor: A decoy target for IL- 1 that is regulated by IL-4. Science 261: 472-475.

11. Sims JE, Gayle MA, Slack JL, et al. (1993) Interleukin 1 signalling occurs exclusively via the type I receptor. Proc. Natl. Acad. Sci. U.S.A. 90: 6155-6159.

12. Dinarello CA. (1991) Interleukin-1 and interleukin-1 antagonism. Blood 77: 1627-1652.

13. Granowitz EV, Clark BD, Mancilla J, Dinarello CA. (1991) Interleukin-1 receptor antagonist competitively inhibits the binding of interleukin-1 to the type II interleukin-1 receptor. J. Biol. Chem. 266: 14147-14150.

14. Granowitz EV, Clark BD, Vannier E, Callahan MV, Dinarello CA. (1992) Effect of interleukin-1 (IL-1) blockade on cytokine synthesis: I. IL-1 receptor antagonist inhibits IL-1-induced cytokine synthesis and blocks the binding of IL-1 to its type II receptor on human monocytes. Blood 79: 2356-2363.

15. Olsson I, Gatanaga T, Gullberg U, Lantz M, Granger FA. (1993) Tumour necrosis factor (TNF) binding proteins (soluble TNF receptor forms) with possible roles in inflammation and malignancy. Eur. Cytokine Net. 4: 169180.

16. Folks TM, Justement J, Kinter A, Dinarello CA, Fauci AS. (1987) Cytokine-induced expression of HIV-1 in a chronically infected promonocytic cell line. Science 238: 800-802.

17. Folks TM, Clouse KA, Justement J, et al. (1989) Tumor necrosis factor $\alpha$ induces expression of human immunodeficiency virus in a chronically infected T-cell clone. Proc. Natl. Acad. Sci. U.S.A. 86: 2365-2368.

18. Poli G, Bressler P, Kinter A, et al. (1990) Interleukin 6 induces human immunodeficiency virus expression in infected monocytic cells alone and in synergy with tumor necrosis factor $\alpha$ by transcriptional and posttranscriptional mechanisms. J. Exp. Med. 172: 151-158.

19. Biswas P, Poli G, Kinter AL, et al. (1992) Interferon $\gamma$ induces the expression of human immunodeficiency virus in persistently infected promonocytic cells (Ul) and redirects the production of virions to intracytoplasmic vacuoles in phorbol myristate acetate-differentiated Ul cells. J. Exp. Med. 176: 739-750.

20. Duh EJ, Maury WJ, Folks TM, Fauci AS, Rabson AB. (1989) Tumor necrosis factor $\alpha$ activates human immunodeficiency virus type 1 through induction of nuclear factor binding to the NF- $\kappa \mathrm{B}$ sites in the long terminal repeat. Proc. Natl. Acad. Sci. U.S.A. 86: 5974-5978.

21. Okamoto $\mathrm{T}$, Matsuyama $\mathrm{T}$, Mori $\mathrm{S}$, et al. (1989) Augmentation of human immunode- 
ficiency virus type 1 gene expression by tumor necrosis factor $\alpha$. AIDS Res. Hum. Retrovir. 5: 131-138.

22. Osborn L, Kunkel S, Nabel GJ. (1989) Tumor necrosis factor $\alpha$ and interleukin 1 stimulate the human immunodeficiency virus enhancer by activation of the nuclear factor $\kappa \mathrm{B}$. Proc. Natl. Acad. Sci. U.S.A. 86: 2336-2340.

23. Kobayashi N, Hamamoto Y, Koyanagi Y, Chen ISY, Yamamoto N. (1989) Effect of interleukin- 1 on the augmentation of human immunodeficiency virus gene expression. Biochem. Biophys. Res. Commun. 165: 715-721.

24. Poli G, Kinter AL, Fauci AS. (1994) Interleukin 1 induces expression of the human immunodeficiency virus alone and in synergy with interleukin 6 in chronically infected U1 cells: Inhibition of inductive effects by the interleukin 1 receptor antagonist. Proc. Natl. Acad. Sci. U.S.A. 91: 108-112.

25. Schindler R, Dinarello CA. (1990) Ultrafiltration to remove endotoxins and other cytokine-inducing materials from tissue culture media and parenteral fluids. BioTechniques 8: 408-413.

26. Dignam JD, Lebovitz RM, Roeder RG. (1983) Accurate transcription initiation by RNA polymerase II in a soluble extract from isolated mammalian nuclei. Nucleic Acids Res. 11: 1475-1489.

27. Andrews NC, Faller DV. (1991) A rapid micropreparation technique for extraction of DNAbinding proteins from limiting numbers of mammalian cells. Nucleic Acids Res. 19: 2499.

28. Singh H, Sen R, Baltimore D, Sharp PA. (1986) A nuclear factor that binds to a conserved sequence motif in transcriptional control elements of immunoglobulin genes. Nature 319: 154-158.

29. Nabel G, Baltimore D. (1987) An inducible transcription factor activates expression of human immunodeficiency virus in $\mathrm{T}$ cells. Nature 326: 711-713.

30. Seckinger $P$, Lowenthal JW, Williamson $K$, Dayer J-M, MacDonald HR. (1987) A urine inhibitor of interleukin 1 activity that blocks ligand binding. J. Immunol. 139: 1546-1549.

31. Elias JA, Reynolds MM, Kotloff RM, Kern JA. (1989) Fibroblast interleukin $1 \beta$ : Synergistic stimulation by recombinant interleukin 1 and tumor necrosis factor and posttranscriptional regulation. Proc. Natl. Acad. Sci. U.S.A. 86: 6171-6175.

32. Ikejima $T$, Okusawa $S$, Ghezzi $P$, van der Meer JWM, Dinarello CA. (1987) Interleu- kin 1 induces tumor necrosis factor (TNF) in human peripheral blood mononuclear cells in vitro and a circulating TNF-like activity in rabbits. J. Infect. Dis. 162: 215-223.

33. Shirakawa F, Chedid M, Suttles J, Pollock BA, Mizel SB. (1989) Interleukin 1 and cyclic AMP induce $\kappa$ immunoglobulin lightchain expression via activation of an NF- $\kappa$ Blike DNA-binding protein. Mol. Cell Biol. 9: 959-964.

34. Bottazzi B, Nobili N, Mantovani A. (1990) Expression of c-fos proto-oncogene in tumor-associated antigen. J. Immunol. 144: 4878-4882.

35. Dinarello CA, Ikejima T, Warner SJ, et al. (1987) Interleukin 1 induces interleukin 1. I. Induction of circulating interleukin 1 in rabbits in vivo and in human mononuclear cells in vitro. J. Immunol. 139: 1902-1910.

36. Fasano MB, Cousart S, Neal S, McCall CE. (1991) Increased expression of the interleukin 1 receptor on blood neutrophils of humans with the sepsis syndrome. J. Clin. Invest. 88: 1452-1459.

37. Griffen GE, Leung K, Folks TM, Kunkel S, Nabel GL. (1989) Activation of HIV gene expression during monocyte differentiation by induction of NF- $\kappa$ B. Nature 339: 70-73.

38. Suzan M, Salaun D, Neuveut C, et al. (1991) Induction of NF- $\kappa \mathrm{B}$ during monocyte differentiation by HIV type 1 infection. J. Immunol. 146: 377-383.

39. Lahdevirta J, Maury CJP, Teppo A-M, Repo H. (1988) Elevated levels of circulating cachectin/tumor necrosis factor in patients with acquired immunodeficiency syndrome. Am. J. Med. 85: 289-291.

40. Reddy MM, Sorrel SJ, Lange M, Grieco MH. (1988) Tumor necrosis factor and HIV-1 p24 antigen levels in serum of HIV-infected population. J. Acquir. Immune Defic. Syndr. 1: 436440.

41. Tadmori W, Mondal D, Tadmori I, Prakash O. (1991) Transactivation of human immunodeficiency virus type 1 long terminal repeats by cell surface tumor necrosis factor $\alpha$. J. Virol. 65: 6425-6429.

42. Poli G, Kinter A, Justement JS, et al. (1990) Tumor necrosis factor $\alpha$ functions in an autocrine manner in the induction of human immunodeficiency virus expression. Proc. Natl. Acad. Sci. U.S.A. 87: 782-785.

43. Butera ST, Roberts BD, Folks TM. (1993) 
Regulation of HIV-l expression by cytokine networks in a CD4+ model of chronic infection. J. Immunol. 150: 625-634.

44. Makonkawkeyoon S, Limson-Pobre RNR, Moreira AL, Schauf V, Kaplan G. (1993)
Thalidomide inhibits the replication of human immunodeficiency virus type 1. Proc. Natl. Acad. Sci. U.S.A. 90: 5974-5978.

45. Dinarello CA. (1992) Anti-cytokine strategies. Eur. Cytokine Net. 3: 7-17.

Contributed by A. S. Fauci on June 28, 1995. 